\title{
Impact of Cluster Thinning on Quality of "Malbec" Grapes in Encruzilhada do Sul-RS
}

\author{
Maria Inez Lopes Fernandes de Barros¹, Dianini Brum Frölech1, Letícia Leal de Mello1, \\ Roberta Manica-Berto2 ${ }^{*}$, Marcelo Barbosa Malgarim1, Vagner Brasil Costa ${ }^{3}$, Paulo Mello-Farias ${ }^{1}$ \\ ${ }^{1}$ Departamento de Fitotecnia, Universidade Federal de Pelotas, Pelotas, Brazil \\ ${ }^{2}$ Tríade-Comunicação Científica, Pelotas, Brazil \\ ${ }^{3}$ Universidade Federal do Pampa, Campus Dom Pedrito, Dom Pedrito, Brazil \\ Email: ^robertamanica@yahoo.com.br
}

How to cite this paper: Barros, M.I.L.F. Frölech, D.B., Mello, L.L., Manica-Berto, R., Malgarim, M.B., Costa, V.B. and Mello-Farias, P. (2018) Impact of Cluster Thinning on Quality of "Malbec" Grapes in Encruzilhada do Sul-RS. American Journal of Plant Sciences, 9, 495-506.

https://doi.org/10.4236/ajps.2018.93037

Received: January 9, 2018

Accepted: February 24, 2018

Published: February 27, 2018

Copyright (C) 2018 by authors and Scientific Research Publishing Inc. This work is licensed under the Creative Commons Attribution International License (CC BY 4.0).

http://creativecommons.org/licenses/by/4.0/

\begin{abstract}
The cultivar Malbec has been present's good performance and quality in the South Half of Rio Grande do Sul (RS). In this context, we aimed to evaluate the quality of "Malbec" grapes in relation to the phytotechnical, physicochemical parameters and bioactive compounds under different intensities of cluster thinning in Encruzilhada do Sul-RS. The experiment was carried out in a commercial vineyard in the 2015/16 with the cultivar Malbec (Vitis vinifera L.) under rootstock "1103 Paulsen", with spacing of $2.2 \mathrm{~m}$ between rows and $1.1 \mathrm{~m}$ between plants. The experimental design was of randomized complete blocks with five replications. The treatment factor tested was the cluster thinning, with four levels $(0 \%, 10 \%, 30 \%$ and $50 \%)$, performed in véraison. The evaluated phytotechnical variables were cluster length, cluster fresh weight, berries fresh weight, number of berries, rachis fresh weight. Also what were determined are the number of clusters, production and Ravaz index. The physicochemical variables verified were $\mathrm{pH}$, soluble solids (SS), titratable acidity (TA) and SS/TA ratio. The bioactive compounds were total polyphenols index and total anthocyanins. The appropriate balance between source and sink, by the Ravaz index, occurs to zero and $10 \%$ of cluster thinning. The "Malbec" grapes present an increase of the maturation index (SS/TA) at $50 \%$ of cluster thinning, due to the low titratable acidity at this level. The total polyphenols index has a larger increment when the plants are submitted to the cluster thinning of $10 \%$, providing a larger quality to the fruits. At all the levels of cluster thinning tested, when compared to the control, there was a greater contribution of total anthocyanins in the berries.
\end{abstract}

\section{Keywords}

Vitis vinifera, Maturation Index, Bioactive Compounds, Ravaz Index, 
Polyphenols

\section{Introduction}

The Highlands of Southeast located in the Southern Half of the State between the municipalities of Pinheiro Machado and Encruzilhada do Sul, in the 1970s, was recognized as propitious for production of $V$. vinifera grapes due to its soft-wavy relief, climate and their geographic characteristics. Since then, national and multinational companies have begun to invest on the region, making the fine grapes finally become of significant importance in the regional and national economy [1] [2].

Malbec is among the grapes produced in Encruzilhada do Sul. It is a cultivar with good potential for varietal wines and can also be used in cuts. Of an intense red, it has aroma of fruits like plums, blackberries and cherries. Considered to be of early maturation, it has medium, cylindrical-conical winged and loose cluster, with medium and black berries, pulpy and quite sweet. This cultivar is very old, originating in the region of Bordeaux, France. It requires a good thermal amplitude so that it can develop its characteristics intensively [3] [4].

The quality of the grape is a result of the interaction of biological factors, such as cultivar, physical conditions, including soil and its management, climate, for example temperature, precipitation, wind speed, direct and indirect solar radiation, but mainly density of planting and the various cultural practices that involve the type of conduction, pruning, fruit load and vegetation management [5] [6] [7]. The right balance between the photosynthetically active foliar surface and the production results in the obtaining of quality wines [8] [9].

In this context, between the management of the grapevine is a cluster thinning that changes the source (vegetation) and sink (fruits) relationship, without reducing the leaf area, causing the plant to concentrate its activities on the regulation of production [10]. The amount of fruit load per plant compromises the size of the clusters and thus the accumulation of sugars [11] and of components related to the supply of polyphenols, which determine the quality of the grape [12]. Therefore, we aimed to evaluate the quality of "Malbec" grapes in relation to the phytotechnical, physicochemical parameters and bioactive compounds under different intensities of cluster thinning in Encruzilhada do Sul-RS.

\section{Materials and Methods}

The experiment was conducted in the 2015/16 harvest in a commercial vineyard installed in 2004 conducted in espalier system, located on the margin of RS/BR 471 , in the municipality of Encruzilhada do Sul ( $30^{\circ} 30^{\prime} 54.73^{\prime \prime} \mathrm{S}, 52^{\circ} 30^{\prime} 14.28^{\prime \prime} \mathrm{W}$ and $375 \mathrm{~m}$ of altitude), Rio Grande do Sul (RS), Brazil. The mean annual values of temperature, precipitation and relative humidity correspond to $17.4^{\circ} \mathrm{C}, 1.533$ $\mathrm{mm}$ and $78 \%$, respectively. Table 1 shows the average monthly values of 
Table 1. Average of temperatures $\left({ }^{\circ} \mathrm{C}\right)$ and precipitation $(\mathrm{mm})$ during the period of the experiment.

\begin{tabular}{ccc}
\hline Harvest $2015 / 16$ & Average temperature $\left({ }^{\circ} \mathrm{C}\right)$ & Precipitation $(\mathrm{mm})$ \\
\hline April/15 & 19.05 & 84.10 \\
May/15 & 15.87 & 186.10 \\
June/15 & 13.53 & 186.00 \\
July/15 & 13.25 & 277.40 \\
August/15 & 17.56 & 97.10 \\
September/15 & 14.73 & 216.80 \\
October/15 & 16.02 & 296.10 \\
November/15 & 18.47 & 108.60 \\
December/15 & 21.44 & 349.10 \\
January/16 & 23.45 & 80.20 \\
\hline
\end{tabular}

temperature and precipitation during the experiment period [13]. According to Köppen classification the climate of the region is type Cfa temperate humid, with hot summers and precipitations well distributed throughout the year [14]. The soil of the area was classified as Red-Yellow Latosol [15].

The cultivar used was Malbec ( V. vinifera) under rootstock "1103 Paulsen" (Vitis berlandieri $\times$ Vitis rupestris $\mathrm{cv}$. 1103P), conducted in a guyot system, with spacing of $2.2 \mathrm{~m}$ between rows and $1.1 \mathrm{~m}$ between plants. The rootstock "1103 Paulsen" has high vigor, with a root system that tends to provide high shoot growth and generally produces larger cluster and berry size, but delayed maturity. The vineyard has $17,050 \mathrm{~m}^{2}, 6200$ plants, with an average of 15.8 branches per plant, 59.5 leaves per branch, and an average leaf area of $44.1 \mathrm{~m}^{2} \cdot$ plant $^{-1}$. The management and cultural practices were carried out following the technical recommendations of the culture [16] [17]. The experimental design was of randomized complete blocks with five repetitions, each repetition composed of a plant. The treatment factor tested was the cluster thinning, with four levels $(0 \%$, $10 \%, 30 \%$ and $50 \%)$. The cluster thinning levels were chosen from directed research on the quality of grapes [6].

When approximately $50 \%$ of the berries were found in the subperiod of color change (véraison), the number of cluster per plant was counted and the manual cluster thinning was performed according to the levels proposed in the study. Pruning shears were used for this practice. The harvest occurred 32 days after the management in February 2016, when the grapes reached $18.9^{\circ}$ Brix. All the evaluations were carried out at the Laboratory of Physicochemical Analyzes of the Federal Institute of Education, Science and Technology Sul-rio-grandense (IFSul), Pelotas Campus-Visconde da Graça, Pelotas-RS.

The evaluated phytotechnical variables were cluster length $(\mathrm{cm})$, cluster fresh weight (g), berries fresh weight (g), number of berries and rachis fresh weight (g) using precision balance and graduated scale. The number of clusters and pro- 
duction per plant were also determined by multiplying the medium number of clusters per plant by the average cluster weight. The production per plant was obtained and the results were expressed in kg.plant ${ }^{-1}$. The Ravaz index (RI) was obtained from the winter dry pruning weight in relation to the production [18], as per Equation (1):

$$
\mathrm{RI}=\mathrm{kg} \text { of fruit } \mathrm{kg} / \mathrm{dry} \text { pruning }
$$

This index indicates the vigor of the vine, where values between four and seven for cultivars $V$. vinifera inform that there is plant balance. Indices above seven indicate excess production; and, values below four, too much vine vigor [19].

The physicochemical variables evaluated were $\mathrm{pH}$, soluble solids, titratable acidity and SS/TA ratio. The $\mathrm{pH}$ was determined with benchtop $\mathrm{pH}$ meter (Quimis ${ }^{\oplus}$, model Q400AS, São Paulo, Brazil), Mettler Toledo electrode (Inlab 413) and temperature adjustment to $20^{\circ} \mathrm{C}$, reading directly into the must.

The soluble solids content (SS) was quantified with a manual digital refractometer $\left(\right.$ Atago $\left.^{\circ}\right)$ and the results were expressed in ${ }^{\circ}$ Brix. For titratable acidity (TA), $10 \mathrm{~mL}$ of grape must was added in $90 \mathrm{~mL}$ of distilled water. The titration of the sample was done using a digital burette $\left(\mathrm{Brand}^{\star}\right)$, containing sodium hydroxide solution $(0.1 \mathrm{~N})$ until reaching $\mathrm{pH} 8.1$ and expressed in milliequivalents per liter (meq. $\left.\cdot \mathrm{L}^{-1}\right)$. The calculation of the maturation index was done by the SS/TA ratio.

The bioactive compounds evaluated were total polyphenols index and total anthocyanins. The total polyphenols index (TPI) was determined according to the method proposed by Ávila [20]. Samples previously diluted with distilled water (1:100) were subjected to spectrophotometer reading (PG Instruments Limited $^{\oplus}$ T90 + UV/VIS) at wavelength $280 \mathrm{~nm}$. The values obtained were applied to the formula: TPI $=$ absorbance reading $\times 100$ (dilution factor).

The determination of total anthocyanins was performed according to the method described by Lees and Francis [21], with adaptations. The samples were homogenized with ethanol-based extraction solution ( $\mathrm{pH}$ 1.00) acidified with hydrochloric acid for one hour. After this homogenization period, were subjected to spectrophotometer reading (PG Instruments Limited ${ }^{\circ}$ T90 + UV/VIS) at wavelength $520 \mathrm{~nm}$, the equipment being previously zeroed with ethanol $\mathrm{pH}$ 1.00. The total anthocyanins content was expressed in mg. $100 \mathrm{~g}^{-1}$ of must.

The data were analyzed for normality by the Shapiro-Wilk's test; to homoscedasticity by the Hartley's test; and, the independence of was by graphic analysis. Subsequently, they were submitted to analysis of variance through the F-test ( $\mathrm{p} \leq$ $0.05)$. Statistically significant, the cluster thinning effect was evaluated by regression models ( $\mathrm{p} \leq 0.05)$, as per Equations (2), (3):

$$
\begin{aligned}
& y=y_{o}+a x \\
& y=y_{o}+a x+b x^{2}
\end{aligned}
$$

where: $y=$ response variable; $y_{o}=$ response variable corresponding to the mini- 
mum or maximum point of the curve; $a=$ estimated maximum value for the response variable; $b=$ slope of the curve; $x=$ cluster thinning (\%). The selection of the model was based on the low residue, low p-value, and high $R^{2}$ and $R^{2}$ adj. When no equation adjustment occurred, cluster thinning levels (\%) were compared with $95 \%$ confidence intervals, these intervals were plotted on the graph and the differences were considered significant when there was no overlap between the vertical bars. The correlation presence between the variables dependent on the study was analyzed using the Pearson correlation coefficient (r).

\section{Results and Discussion}

The assumptions of the mathematical model were all attended, and do not was necessary the data transformation for all variables. For the cluster fresh weight $(\mathrm{F}=0.83, \mathrm{p}=0.533)$, berries fresh weight $(\mathrm{F}=0.60, \mathrm{p}=0.6422)$, number of berries $(\mathrm{F}=0.33, \mathrm{p}=0.8027)$, rachis fresh weight $(\mathrm{F}=1.36, \mathrm{p}=0.3553)$ and $\mathrm{pH}(\mathrm{F}=$ $1.44, p=0.3027)$ was not observed significance for the cluster thinning effect (Table 2). Comparing this experiment with that carried out in the same area by Barros et al. [22], with cluster thinning in the Pinot Noir cultivar, there was no significant difference for any of the phytotechnical variables. Thus was also to the study by Ventura [23] and Santos et al. [24] in the Serra Gaúcha, with the cultivar Cabernet Sauvignon.

For cluster length was fitted squared polynomial regression model (Figure 1 (a)). The $30 \%$ cluster thinning in Encruzilhada do Sul, increased by $101.56 \%$ in relation to the control (without cluster thinning). The increase in this level was benefited by the reduction of number of clusters, a fact that was justified by the negative correlation between these variables $(r=-0.80, \mathrm{p}=0.0003)$ (Table 3$)$. In the 2009/10 harvest, a linear constant was observed for the different intensities of thinning for cluster length with "Cabernet Franc" in São Joaquim/Santa Catarina and in 2010/11 as the intensity of cluster thinning increased, this parameter decreased [25].

The behavior of the variables, number of clusters, production and Ravaz index were explained using a linear regression model (Figure 1(b), Figure 1(c) and Figure 1(d)), with a reduction in the values of these parameters with the increase of the percentage of cluster thinning. This fact was reported in both

Table 2. Phytotechnical variables and $\mathrm{pH}$ of "Malbec" grapes in function different intensities of cluster thinning.

\begin{tabular}{|c|c|c|c|c|c|}
\hline Cluster thinning (\%) & Cluster fresh weight (g) & Berries fresh weight (g) & Number of berries & Rachis fresh weight (g) & $\mathrm{pH}$ \\
\hline 0 & $123.43 \pm 18.63^{1 / \mathrm{NS}}$ & $1.51 \pm 0.16^{\mathrm{NS}}$ & $71.00 \pm 5.03^{\mathrm{NS}}$ & $5.50 \pm 1.44^{\mathrm{NS}}$ & $3.32 \pm 0.01^{\mathrm{NS}}$ \\
\hline 10 & $130.67 \pm 12.42$ & $1.19 \pm 0.12$ & $61.33 \pm 1.20$ & $5.60 \pm 0.80$ & $3.39 \pm 0.05$ \\
\hline 30 & $155.27 \pm 45.37$ & $1.43 \pm 0.41$ & $89.50 \pm 8.50$ & $7.77 \pm 2.56$ & $3.39 \pm 0.03$ \\
\hline 50 & $122.53 \pm 37.20$ & $1.09 \pm 0.35$ & $57.33 \pm 26.49$ & $7.27 \pm 0.29$ & $3.39 \pm 0.00$ \\
\hline C.V.(\%) & 28.6 & 36.5 & 41.5 & 23.3 & 1.5 \\
\hline
\end{tabular}

${ }^{1 /}$ Means \pm standard error. ${ }^{\text {NS }}$ : not significance by the F-test $(\mathrm{p} \leq 0.05)$ of the analysis of variance. C.V: coefficient of variation. 
(a)

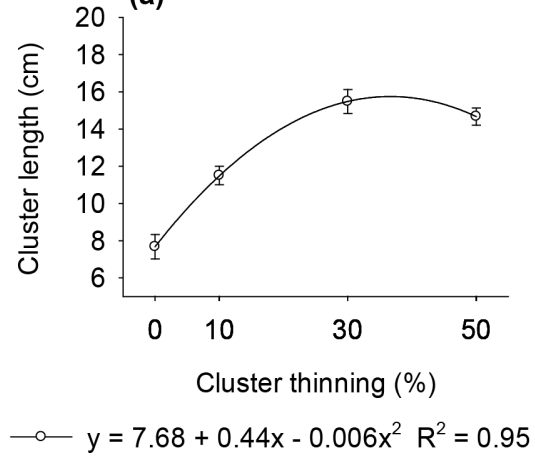

(c)

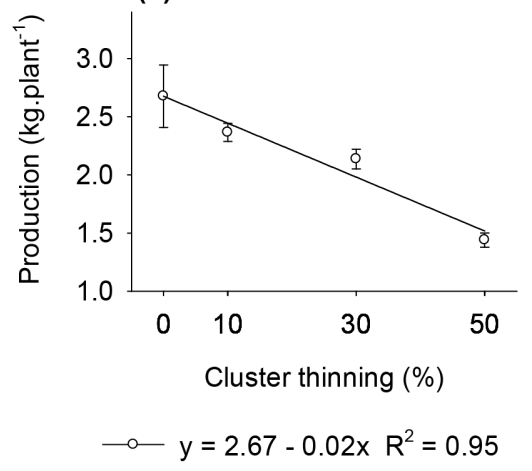

(b)

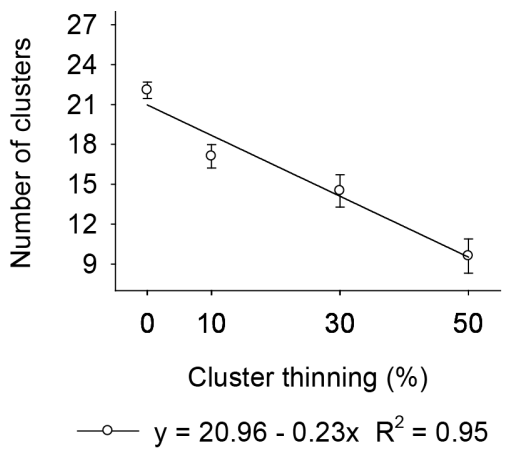

(d)

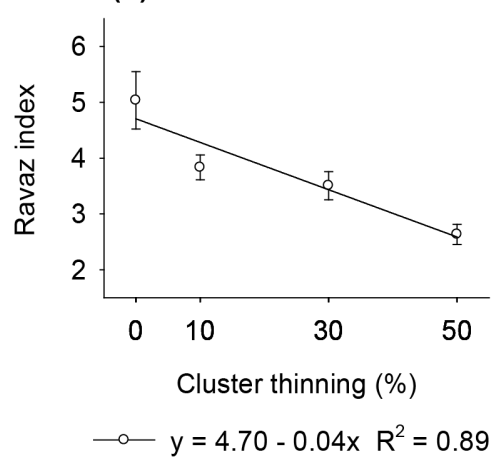

Figure 1. Cluster length $(\mathrm{cm})(\mathrm{a})$; number of clusters (b); production $\left(\mathrm{kg} \cdot\right.$ plant $\left.^{-1}\right)(\mathrm{c})$; and, Ravaz index (d) of "Malbec" grapes in function different intensities of cluster thinning. (Vertical bars represent confidence intervals 95\%).

"Cabernet Sauvignon" and "Merlot" with a reduction in the number of clusters and consequently in the production, when passing from $50 \%$ to $75 \%$ of thinning [26].

For number of clusters, there were decreases of $11.0 \%, 32.9 \%$ and $54.9 \%$, respectively for $10 \%, 30 \%$ and $50 \%$ when compared to the control (without cluster thinning). In the same way, but with lower decreases, the production per plant got, $7.5 \%, 22.5 \%$ and $37.5 \%$ for the same comparisons (Figure 1(c) and Figure 1(d)). Testing cluster thinning with "Cabernet Sauvignon" and "Merlot", there were decreases on average of $67 \%$ in the production for both cultivars studied in the two harvests, comparing with the control [27], reinforcing thus, the results of this study.

The Ravaz index presented values estimated by the established model $4.7 \%$, $4.3 \%, 3.5 \%$ and $2.7 \%$ to $0 \%, 10 \%, 30 \%$ and $50 \%$ cluster thinning, respectively. For ideal values between four and seven, only zero and $10 \%$ of cluster thinning presented balanced results between vigor and fruit yield [19]. These indices were confirmed in "Cabernet Sauvignon" and "Pinot Noir", but with 50\% of cluster thinning in 2009 in Chile [28].

The $\mathrm{pH}$ did not differ between the loads left per plant staying between 3.32 and 3.39 (Table 2). This parameter is one of the important characteristics of the red wine, because besides interfering in color, exerts a pronounced perception 
Table 3. Pearson correlation coefficients $(r)$ and $p$-values among the evaluated variables of "Malbec" grapes in function different intensities of cluster thinning.

\begin{tabular}{|c|c|c|c|c|c|c|c|c|c|c|c|c|c|c|}
\hline Variables & CL (1) & CFW (2) & BFW (3) & NB (4) & RFW (5) & NC (6) & PR (7) & IR (8) & $\mathrm{pH}(9)$ & SS (10) & TA (11) & SS/AT (12) & TPI (13) & TA (14) \\
\hline \multirow[t]{2}{*}{ (1) } & 1.000 & $0.157^{*}$ & -0.154 & -0.023 & 0.425 & -0.803 & -0.549 & -0.592 & 0.523 & 0.367 & -0.636 & 0.718 & 0.045 & 0.774 \\
\hline & & $0.625^{* *}$ & 0.632 & 0.947 & 0.169 & 0.0003 & 0.028 & 0.026 & 0.081 & 0.268 & 0.036 & 0.013 & 0.909 & 0.014 \\
\hline \multirow[t]{2}{*}{ (2) } & & 1.000 & 0.996 & 0.931 & 0.764 & 0.035 & -0.112 & 0.063 & 0.402 & 0.315 & 0.281 & -0.210 & -0.229 & 0.216 \\
\hline & & & $<0.0001$ & $<0.0001$ & 0.004 & 0.914 & 0.729 & 0.863 & 0.284 & 0.409 & 0.463 & 0.587 & 0.585 & 0.642 \\
\hline \multirow[t]{2}{*}{ (3) } & & & 1.000 & 0.916 & 0.730 & 0.252 & 0.020 & 0.144 & 0.234 & 0.248 & 0.392 & -0.343 & -0.215 & 0.176 \\
\hline & & & & $<0.0001$ & 0.011 & 0.454 & 0.951 & 0.690 & 0.515 & 0.490 & 0.262 & 0.332 & 0.609 & 0.706 \\
\hline \multirow[t]{2}{*}{ (4) } & & & & 1.000 & 0.466 & 0.151 & -0.010 & -0.037 & 0.234 & 0.239 & 0.368 & -0.315 & -0.364 & 0.125 \\
\hline & & & & & 0.174 & 0.677 & 0.976 & 0.919 & 0.515 & 0.506 & 0.295 & 0.375 & 0.375 & 0.790 \\
\hline \multirow[t]{2}{*}{ (5) } & & & & & 1.000 & -0.236 & -0.318 & -0.216 & 0.678 & 0.730 & 0.148 & 0.044 & -0.015 & 0.454 \\
\hline & & & & & & 0.461 & 0.314 & 0.549 & 0.045 & 0.026 & 0.703 & 0.910 & 0.971 & 0.305 \\
\hline \multirow[t]{2}{*}{ (6) } & & & & & & 1.000 & 0.899 & 0.775 & -0.378 & -0.288 & 0.772 & -0.858 & 0.344 & -0.495 \\
\hline & & & & & & & $<0.0001$ & 0.002 & 0.252 & 0.419 & 0.009 & 0.001 & 0.364 & 0.175 \\
\hline \multirow[t]{2}{*}{ (7) } & & & & & & & 1.000 & 0.895 & -0.284 & -0.291 & 0.442 & -0.539 & 0.491 & -0.297 \\
\hline & & & & & & & & $<0.0001$ & 0.371 & 0.386 & 0.173 & 0.087 & 0.179 & 0.437 \\
\hline \multirow[t]{2}{*}{ (8) } & & & & & & & & 1.000 & -0.357 & -0.217 & 0.397 & -0.472 & 0.337 & -0.291 \\
\hline & & & & & & & & & 0.255 & 0.520 & 0.226 & 0.143 & 0.375 & 0.448 \\
\hline \multirow[t]{2}{*}{ (9) } & & & & & & & & & 1.000 & 0.561 & -0.527 & 0.679 & 0.130 & 0.486 \\
\hline & & & & & & & & & & 0.072 & 0.096 & 0.022 & 0.739 & 0.184 \\
\hline \multirow[t]{2}{*}{ (10) } & & & & & & & & & & 1.000 & 0.110 & 0.188 & -0.520 & 0.011 \\
\hline & & & & & & & & & & & 0.747 & 0.580 & 0.186 & 0.979 \\
\hline \multirow[t]{2}{*}{ (11) } & & & & & & & & & & & 1.000 & -0.954 & -0.077 & -0.544 \\
\hline & & & & & & & & & & & & $<0.0001$ & 0.855 & 0.163 \\
\hline \multirow[t]{2}{*}{ (12) } & & & & & & & & & & & & 1.000 & -0.137 & 0.452 \\
\hline & & & & & & & & & & & & & 0.746 & 0.261 \\
\hline \multirow[t]{2}{*}{ (13) } & & & & & & & & & & & & & 1.000 & 0.590 \\
\hline & & & & & & & & & & & & & & 0.123 \\
\hline (14) & & & & & & & & & & & & & & 1.000 \\
\hline
\end{tabular}

${ }^{*}$ Pearson correlation coefficient (r). ${ }^{* *}$-values. CL: cluster length; CFW: cluster fresh weight; BFW: berries fresh weight; NB: number of berries; RFW: rachis fresh weight; NC: number of clusters; PR: production; RI: Ravaz index; SS: soluble solids; TA: titratable acidity; TPI: total polyphenols index; TA: total anthocyanins.

on taste [29]. Working with clusters thinning in the "Cabernet Sauvignon" in Bom Retiro/Santa Catarina, were presented values between 3.7 and 3.9 in the 2004/05 harvest [30], somewhat above average, than for musts in red grapes, the variation should be between 3.3 and 3.6 [31]. Therefore, all the cluster thinning tested in this study were within the established standard. For soluble solids (SS) it was not possible to regression model fit (Figure 2(a)). The $10 \%$ cluster thinning was the one that presented the lowest content of SS, differing from the others that remained more balanced. 
(a)

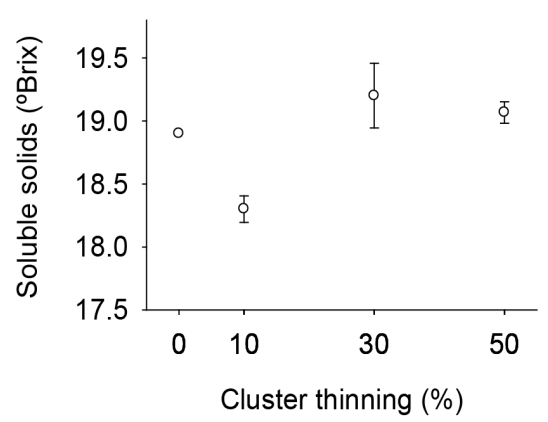

(c)

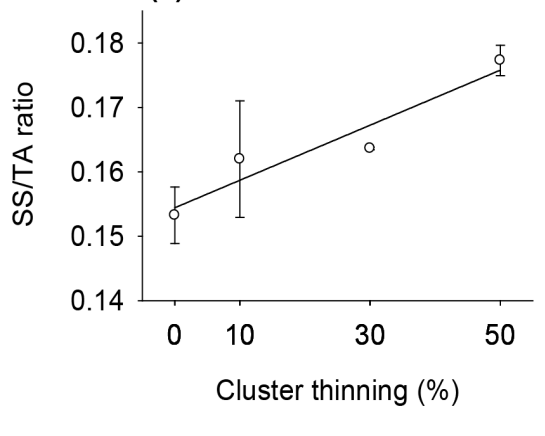

(b)

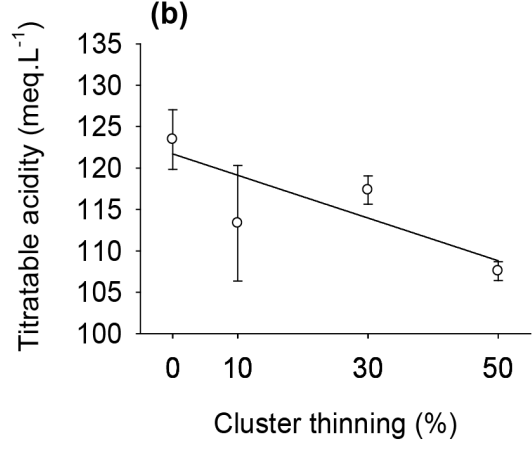

$\multimap y=0.15+0.0004 x R^{2}=0.91$

(e)

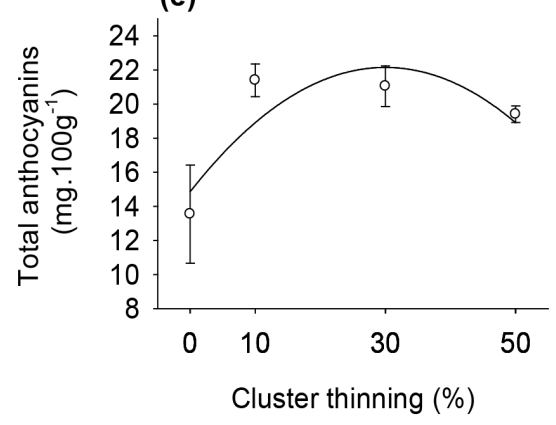

$$
\multimap y=14.86+0.48 x-0.008 x^{2} R^{2}=0.60
$$

Figure 2. Soluble solids-SS ( ${ }^{\circ}$ Brix) (a); titratable acidity-TA (meq $\left.\cdot \mathrm{L}^{-1}\right)(\mathrm{b})$; SS/TA ratio (c); total polyphenols index (d); and, total anthocyanins (mg $100 \mathrm{~g}^{-1}$ ) (e) of "Malbec" grapes in function different intensities of cluster thinning. (Vertical bars represent confidence intervals 95\%).

The titratable acidity data were adjusted to the linear regression model (Figure 2(b)), with decreases of $2.1 \%, 6.4 \%$ and $10.7 \%$ for $10 \%, 30 \%$ and $50 \%$, respectively, when compared to the without thinning. This result was also observed in the studies carried out with "Cabernet Sauvignon" and "Cabernet Franc", where regression was also linear as the cluster thinning intensities increased [30] [32].

Likewise, the SS/AT ratio data were adjusted to the linear regression model (Figure 2(c)). The increases for the maturation index at all thinning levels, when 
compared to the control, are due to the reduction of acidity, a result confirmed by the negative correlation between these variables $(r=-0.95, \mathrm{p}<0.0001)$ (Table 3), and, consequently, the cluster thinning of $50 \%$, the result that obtained the greatest increase.

For the total polyphenol index, no regression model fit was observed (Figure $2(d)$ ). The highest total polyphenol contents were verified with $10 \%$ cluster thinning, which differed from the others. These contents were observed in vines where the fruit load was balanced in relation to the vigor of the plant, confirmed by the Ravaz index (Figure 1(d)). Contrary to that verified in this study, Mota et al. [26] verified an increase in total polyphenol contents when the cluster thinning increased from $50 \%$ to $75 \%$, combined with the shoot trimming.

While for total anthocyanins, data were adjusted to the quadratic polynomial regression model (Figure 2(e)). Positive effect of cluster thinning was also verified by other authors, who reported, in addition to the increase of anthocyanins, the increase in $\mathrm{pH}$, soluble solids content and total phenolic compounds [33] [34] [35]. The cluster thinning was reported, in addition to increasing the anthocyanin content in the shell of the berry, can also cause a change in your profile [36] [37] and expression of genes, such as MYB5b, MYBPA1 and VlMYBA2, related to its biosynthesis [38].

The highest coefficients of positive correlations occurred between cluster fresh weight and berries fresh weight $(r=0.99, \mathrm{p}<0.0001)$ and number of berries $(r=$ $0.93, \mathrm{p}<0.0001)$, evidencing that the increase in fresh weight and number of berries resulted in an increase in cluster fresh weight. This same behavior was verified between berries fresh weight with number of berries $(r=0.91, \mathrm{p}<$ $0.0001)$ and rachis fresh weight $(r=0.73, \mathrm{p}=0.011)$. Besides these, other variables had a similar response, such as number of clusters with production $(r=$ $0.90, \mathrm{p}<0.0001)$ and TA $(r=0.77, \mathrm{p}<0.009)($ Table 3$)$.

\section{Conclusion}

The appropriate balance between source and sink, by the Ravaz index, occurs to zero and $10 \%$ of cluster thinning. The "Malbec" grapes present an increase of the maturation index (SS/AT) at $50 \%$ of cluster thinning, due to the low titratable acidity at this level. The total polyphenols index has a larger increment when the plants are submitted to the cluster thinning of $10 \%$, providing a larger quality to the fruits. At all the levels of cluster thinning tested, when compared to the control, there was a greater contribution of total anthocyanins in the berries.

\section{Acknowledgements}

The authors express their gratitude to the Coordenação de Aperfeiçoamento de Pessoal de Nível Superior (CAPES).

\section{Conflicts of Interest}

There are no conflicts of interest in present study. 


\section{References}

[1] Protas, J.F. da S. and Camargo, U.A. (2011) Vitivinicultura Brasileira. Panorama Setorial 2010. [Brazilian Viticulture. Sectorial Panorama 2010.] 1st Edition, SEBRAE, Brasília; IBRAVIN, Embrapa Uva e Vinho, Bento Gonçalves, 110.

[2] Tonietto, J., Ruiz, V.S. and Gómez-Miguel, V.D. (2012) Clima, zonificación y tipicidaddelvino enregiones vitivinícolas iberoamericanas. [Climate, Zoning and Typicity of wine in Iberoamerican Viticultural Regions.] 1st Edition, CYTED, Madrid, 411.

[3] de Sousa, J.S.I. (2002) Viticultura brasileira: principais variedades e suas características. [Brazilian Viticulture: Main Varieties and Their Characteristics.] 9th Edition, FEALQ, Piracicaba, 368.

[4] Goldner, M.C. (2008) Caracterización sensorial y físicoquimica de vinos Chardonnay y Malbec de distintas regiones vitivinícolas argentinas. Ph.D. Thesis, Universidade de Buenos Aires, Buenos Aires.

[5] Disegna, E., Coniberti, A. and Dellacassa, E. (2005) Medición de área foliar de la vid: una herramienta para producir vinos de calidad. Revista INIA, 4, 18-20.

[6] Almanza-Merchán, P.J., Fischer, G., Serrano-Cely, P.A., Balaguera-López, H.E. and Galvis, J.A. (2011) Effects of Leaf Removal and Cluster Thinning on Yield and Quality of Grapes (Vitisvinifera L., Riesling $\times$ Silvaner) in Corrales, Boyaca (Colombia). Agronomía Colombiana, 29, 35-42.

[7] Quijano, R. (2011) Investigación e innovaciónPromoción y defensa del “terroir” regional. Cultura Cientifica, 4, 35-41.

[8] Lavín, A.A., Gutierrez, A.T. and Rojas, M.S.C. (2001) Niveles de carga en viñedos jóvenes cv. Chardonnay y sus efectos sobre producción y calidad del vino. Agricultura Técnica, 61, 26-34.

[9] Hernández, D.M.S. and Moreno, P.M. (2005) Viticultura: técnicas de cultivo de la vid, calidad de la uva y atributos de losvinos. [Viticulture: Grape Cultivation Techniques, Grape Quality and Wine Attributes.] 1st Edition, Mundi-Prensa, Madrid, 325.

[10] Matus, M.S., Rodríguez, J.G. and Ocvirk, M.M. (2006) Raleo de racimos en Vitis vinifera cv. Malbec. Efecto sobre los componentes delrendimiento y la composiciónpolifenólica de lasbayas. Revista de la Facultad de Ciencias Agrarias, 38, 105-112.

[11] Iacono, F., Bertamini, M., Scienza, A. and Coombe, B.G. (1995) Differential Effects of Canopy Manipulation and Shading of Vitis vinifera L. cv. Cabernet Sauvignon. Leaf Gas Exchange, Photosynthetic Electron Transport Rate and Sugar Accumulation in Berries. Vitis_-Journal of Grapevine Research, 34, 201-206.

[12] Reynolds, A.G. and Wardle, D.A. (1989) Impact of Various Canopy Manipulation Techniques on Growth, Yield, Fruit Composition, and Wine Quality of Gewürztraminer. American Journal of Enology and Viticulture, 40, 121-129.

[13] INMET Instituto Nacional de Meteorologia (2017). http://www.inmet.gov.br

[14] Köppen, W. and Geiger, R. (1928) Climates of the Earth. Verlag Justus Perthes, Gotha.

[15] Embrapa, Centro Nacional de Pesquisa do Solo (CNPS) (2006) Brazilian System of Soil Classification. 2nd Edition, Embrapa Solos, Rio de Janeiro, 306.

[16] Pommer, C.V. (2003) Grape: Production Technology, Post-Harvest, Market. Cinco Continentes, Porto Alegre, 778.

[17] Giovannini, E. (2014) Manual of Viticulture: Axis Food Production Natural Re- 
sources. Bookman, Porto Alegre, 264.

[18] Ravaz, L. (1903) Sur la brunissure de la vigne. Les Comptes Rendus de P Académie des Sciences, 136, 1276-1278.

[19] Yuste, D.J. (2005) Factores de desequilibrio de lavid: alternativas para el manejo eficaz del potencial vegetativo hacia el equilibrio del viñedo. In: Control del vigor $y$ del rendimiento en el marco de una viticultura de calidad, Anais APROVI, La Rioja, $1-15$.

[20] Ávila, L.D. (2002) Metodologias analíticas físico-químicas-Laboratório de Enologia. CEFET, Bento Gonçalves, 68.

[21] Lees, D.H. and Francis, F.J. (1972) Standardization of Pigment Analyses in Cranberries. HortScience, 7, 83-84.

[22] Barros, M.I.L.F., Frölech, D.B., Mello, L.L., Lamela, C.S., Assis, A.M. and Malgarim, M.B. (2016) Qualidades físicas das uvas "Pinot Noir" submetidas a intensidades de raleio de cachos na Serra do Sudeste RS. Revista Congrega Urcamp, 13, 1045-1053.

[23] Ventura, D.W. (2008) Qualidade da uva "Cabernet Sauvignon" no sistema de condução latada em função da intensidade de raleio de cachos. Dissertation, Universidade do Estado de Santa Catarina, Lages.

[24] Santos, H.P., Amarante, C.V.T., Steffens, C.A., Ventura, D.W. and Miqueloto, A. (2010) A Qualidade da uva "Cabernet Sauvignon" submetida ao raleio de cachos no sistema de condução latada. Revista de Ciências Agroveterinárias, 9, 160-168.

[25] Marcon Filho, J.L. (2012) Raleio de cachos sobre a qualidade da uva e do vinho da cultivar Cabernet Franc em região de altitude. Dissertation, Universidade do Estado de Santa Catarina, Lages.

[26] Mota, R.V. da, Souza, C.R. de, Silva, C.P.C., Freitas, G.F., Shiga, T.M., Purgatto, E., Lajolo, F.M. and Regina, M.A. (2010) Biochemical and Agronomical Responses of Grapevines to Alteration of Source-Sinkratio by Clusters Thinning and Shoot Trimming. Bragantia, 69, 17-25. https://doi.org/10.1590/S0006-87052010000100004

[27] Karoglan, M., Osrečak, M., Maslov, L. and Kozina, B. (2014) Effect of Cluster and Berry Thinning on Merlot and Cabernet Sauvignon Wines Composition. Czech Journal of Food Sciences, 32, 470-476.

[28] Cañón, P.M., González, A.S., Alcalde, J.A. and Bordeu, E. (2014) Red Wine Phenolic Composition: The Effects of Summer Pruning and Clusters Thinning. Ciencia e Investigación Agraria, 41, 235-248.

[29] Somers, T.C. (1977) A Connection between Potassium Levels in the Harvest and Relative Quality in Australian Red Wines. Australian Wine, Brewing and Spirit Review, 24, 32-34.

[30] Penter, F. (2006) Efeito do raleio de cachos na qualidade dos frutos da videira Cabernet Sauvignon produzida na Serra Catarinense. Dissertation, Universidade do Estado de Santa Catarina, Lages.

[31] Jackson, R.S. (2008) Wine Science: Principles and Applications. 3rd Edition, Academic Press, London, 776.

[32] Marcon Filho, J.L., Hipólito, J.S., Macedo, T.A. de, Kretzschmar, A.A. and Rufato, L. (2015) Raleio de cachos sobre o potencial enológico da uva "Cabernet Franc" em duas safras. Ciência Rural, 45, 2150-2156. https://doi.org/10.1590/0103-8478cr20140995

[33] Guidoni, S., Allara, P. and Schubert, A. (2002) Effect of Cluster Thinning on Berry Skin Anthocyanin Composition of Vitis vinifera cv. Nebbiolo. American Journal of Enology and Viticulture, 53, 224-226. 
[34] Prajitna, A., Dami, I.E., Steiner, T.E., Ferree, D.C., Scheerens, J.C. and Schwartz, S.J. (2007) Influence of Cluster Thinning on Phenolic Composition, Resveratrol, and Antioxidant Capacity in Chambourcin Wine. American Journal of Enology and Viticulture, 58, 346-350.

[35] Bubola, M., Peršurić, Đ. and Kovačević Ganić, K. (2011) Impact of Cluster Thinning on Productive Characteristics and Wine Phenolic Composition of cv. Merlot. Journal of Food, Agriculture \& Environment, 9, 36-39.

[36] Guidoni, S., Ferrandino, A. and Novello, V. (2008) Effects of Seasonal and Agronomical Practices on Skin Anthocyanin Profile of Nebbiolo Grapes. American Journal of Enology and Viticulture, 59, 22-29.

[37] Pastore, C., Zenoni, S., Tornelli, G.B., Allegro, G., Santo, S.D., Valentini, G., Intrieri, C., Pezzotti, M. and Filippetti, I. (2011) Increasing the Source/Sink Ratio in Vitis vinifera (cv. Sangiovese) Induces Extensivetranscriptome Reprogramming and Modifies Berry Ripening. BioMed Central Genomics, 12, 631-654.

[38] Xi, X., Zha, Q., Jiang, A. and Tian, Y. (2016) Impact of Cluster Thinning on Transcriptional Regulation of Anthocyanin Biosynthesis-Related Genes in "Summer Black" Grapes. Plant Physiology and Biochemistry, 104, 180-187.

https://doi.org/10.1016/j.plaphy.2016.03.015 